\title{
ORDINARY KRIGING FOR THE ESTIMATION OF VEIN TYPE COPPER DEPOSIT: A CASE STUDY OF THE CHELKUREH, IRAN
}

\author{
Ali Akbar Daya ${ }^{\#}$ \\ University of Sistan and Baluchestan, Department of Mining Engineering, Zahedan, Iran
}

(Received: February 18, 2015; Accepted: October 5, 2015)

\begin{abstract}
Estimation of mineral resources and reserves with low values of error is essential in mineral exploration. The aim of this study is to estimate and model a vein type copper deposit using ordinary kriging method. After studying of variograms in different directions it was found out that the ore deposit has no anisotropy. The best fitted variogram model was considered for ordinary kriging estimation. Cross-validation was used to evaluate the accuracy of the variogram model for kriging. After trial and error a variogram with the best summary statistics was chosen. Model consists of a pure nugget effect with 0,30 amplitude plus a spherical scheme with sill 1.10 and range $30 \mathrm{~m}$. The cross validation results showed that the correlation coefficient between estimated and real data was 0.829 . The resource was classified based on calculated estimation errors by JORC code. Results showed that ordinary kriging can be used to model and estimate the vein type deposit. Consequently a three dimensional model of estimated value and error estimated value was provided by ordinary kriging to divide the ore into an economic and uneconomic part.
\end{abstract}

Key words: Ordinary kriging, JORC classification, Vein type, Chelkureh.

\section{Introduction}

Geostatistics is concerned with spatial data. That is, each data value is associated with a location in space and there is at least an implied connection between the location and the data value. Location refers often to a point in space (in an abstract mathematical sense) and can be associated with an area or volume in space [1].

Geostatistics provides a coherent framework for spatial prediction. Estimation is possible due to spatial correlation, i.e. the underlying biophysical phenomenon causes observations that are measured closely to be dependent on one and another. If the unknown values at the un-sampled location were dependent on the known sample value at another location, then those sample values carry information about the unknown [1].

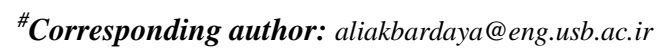

Geostatistics is usually believed to have originated from the work in geology and mining by Krige (1951), but it can be traced back to the early 1910s in agronomy and 1930s in meteorology [2]. It was developed by Matheron (1963) with his theory of regionalised variables [3]. Geostatistics includes several methods that use kriging algorithms for estimating continuous attributes. Kriging is a generic name for a family of generalised least-squares regression algorithms, used in recognition of the pioneering work of Daniel Krige (1951).

Kriging is known to be able to generate not only optimal estimation for a regionalized variable at unsampled locations but also measures (i.e., Kriging variance) of precision concerning the estimation. The information we have about a spatially varying phenomenon is usually incomplete. Most often, only few samples of the variable under 
study are available, next to an abundance of indirect information gathered with remote sensing devices. This implies that one cannot determine with full confidence the exact unknown true outcome of that variable at every location [1].

An important problem in mineral exploration is the estimation of two- or threedimensional regional variables in a studied area, especially ore grade distribution.
According to this problem, which is known as spatial interpolation, several methods were proposed which consist of linear and nonlinear kriging methods, inverse distance weighted (IDW), interpolating polynomials, splines, and power and Fourier series fitting [4]. Ordinary kriging is now well accepted method in mining grade control and mine reserve estimation.

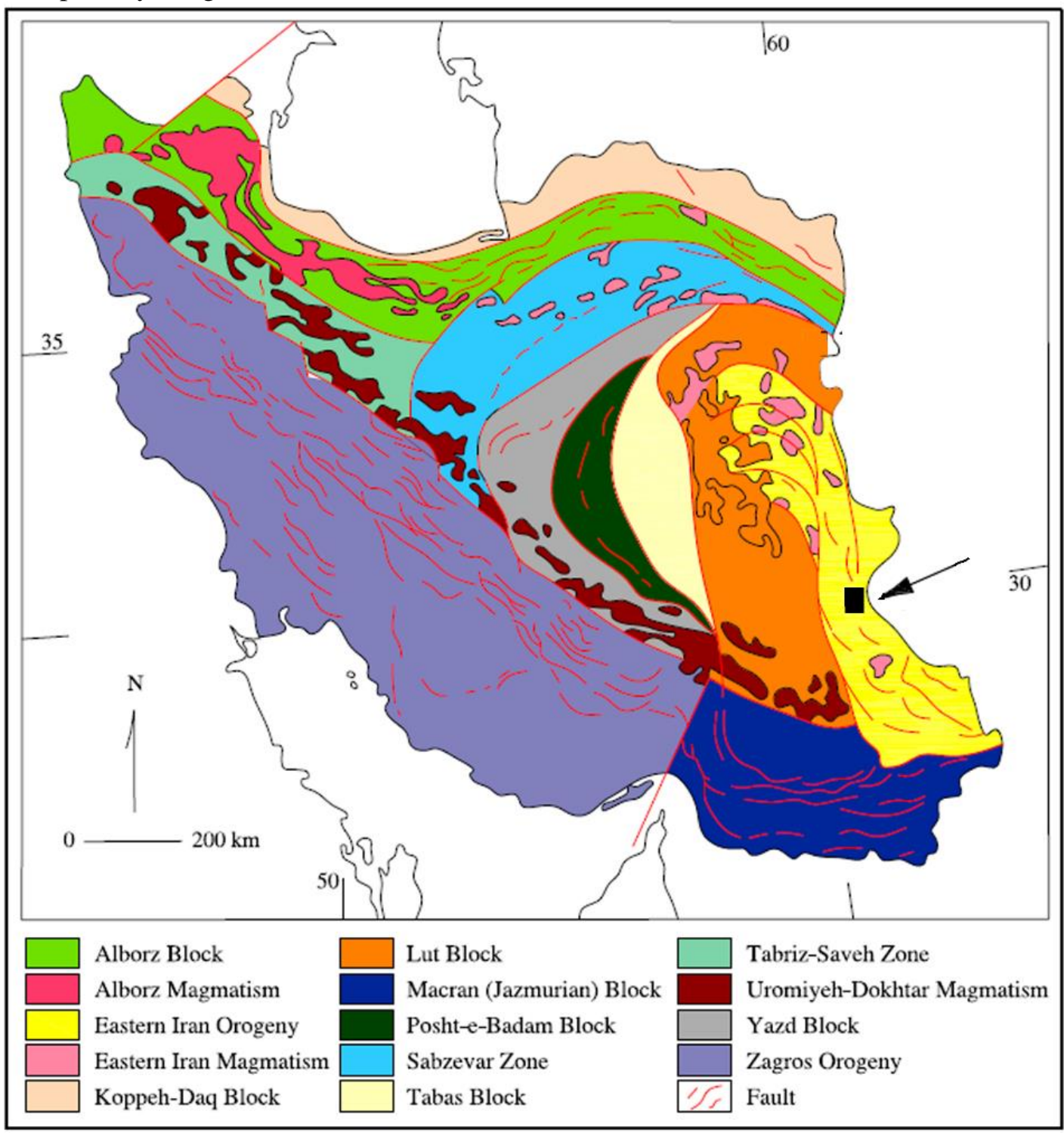

Figure 1. Location of studied area in structural map of Iran (black square; [5]) 
The aim of this study is to evaluate the potential and applicability of ordinary kriging method, as a tool for estimating the reserve of Chelkureh copper deposit. Ordinary kriging was used to estimate the regionalized variable $(\mathrm{Cu}$ Concentration) at unsampled locations. After that a three dimensional model of estimated value is presented by ordinary kriging. The study showed that ordinary kriging can be applied successfully for modeling the grade of an ore deposit. Results showed that the correlation between the estimated value and the real value at locations is $82.9 \%$.

\section{Geological setting of Chelkureh deposit}

The Chelkureh deposit is located in the Nehbandan- Khash zone (eastern Iran) between the Afghan block to the east, the Neh Fault to the west, and the Bashagard Fault to the south [5]. This zone, also known as the Sistan suture zone of eastern Iran [6], represents a narrow, short-lived strip of oceanic lithosphere that was consumed in the Sennonian and Paleogene and, in part, obducted during the Eocene continental collision (Fig. 1) [6].

Dikes and lavas from the Chelkurehophiolitic mélange are plagioclasephyric basalts with chemical compositions that indicate that they were mid-ocean ridge and marginal basin tholeiites [7]. There is no metasedimentary rock older than Cretaceous in the Sistan suture zone[8]. The Cretaceous facies consists of flysch (turbidite) sediments and volcanic rocks [5] up to $3 \mathrm{~km}$ thick. The turbidites are strongly tectonized and underwent low-grade metamorphism (e.g., zeolite-subgreenschistfacies) during the Cretaceous, which converted them to slate, phyllite, and schist. The N-S-trending LunkaMalusan Mountain Range is the highest in the region, with Kuh-e-Lunka (2,300-m elevation) comprising metaturbidites (Fig.2) and Kuh-eMalusan (2,425-m elevation) comprising gabbro [8]. The study area is divided into three lithotypes on the basis of rock components: igneous rocks (younger than ophiolites), sedimentary rocks, and the ophiolitic mélange (Fig. 2). Each of these lithotypes is described below, relative to its age (i.e., from the oldest to the youngest unit). Sedimentary layers, which consist of graywacke, shale, and limestone, are tightly folded, steeply dipping, and faulted [8]. Cretaceous turbidites have faulted contacts with the ophiolitic complex and are composed of phyllite and small lenses of marble [8]. Paleoceneturbidites are composed of shale and sandstone with rare limestone layers (Fig.2).

Eocene turbidites are up to $1 \mathrm{~km}$ thick and widespread. In metamorphosed turbidites the basal conglomerate is the oldest unit. The western turbidites, which are altered, host the Chelkurehoredeposit[18].Several granitoidstocks and dikes intruded the sedimentary sequence where they are oriented parallel to the major NWSE- trending fault set (Fig.2). Plutonic rocks crop out mostly to the west of the Chelkureh Fault in the Lunka-Malusan Mountain Range [9]. Intrusive bodies consist of quartzmonzodiorite and granodiorite at the Chelkureh deposit. Exposures of rock in the vicinity of the Chelkureh deposit are controlled by major N-S- and NW-SEtrending faults, based on air photo lineaments, surface traces, and offsets of geologic features [8]. The strata in the western part of the area, as well as the enclosing faults belonging to the Neh fault system, have an N-S trend.

The Neh fault system is a dominantly right-lateral strike-slip set of faults that have been recently active. The $\mathrm{N}$-S-trending Khanibeyk Fault (the eastern branch of Neh Fault) and northwest-southeast Chelkureh Fault are the most important faults in the area [8]. 

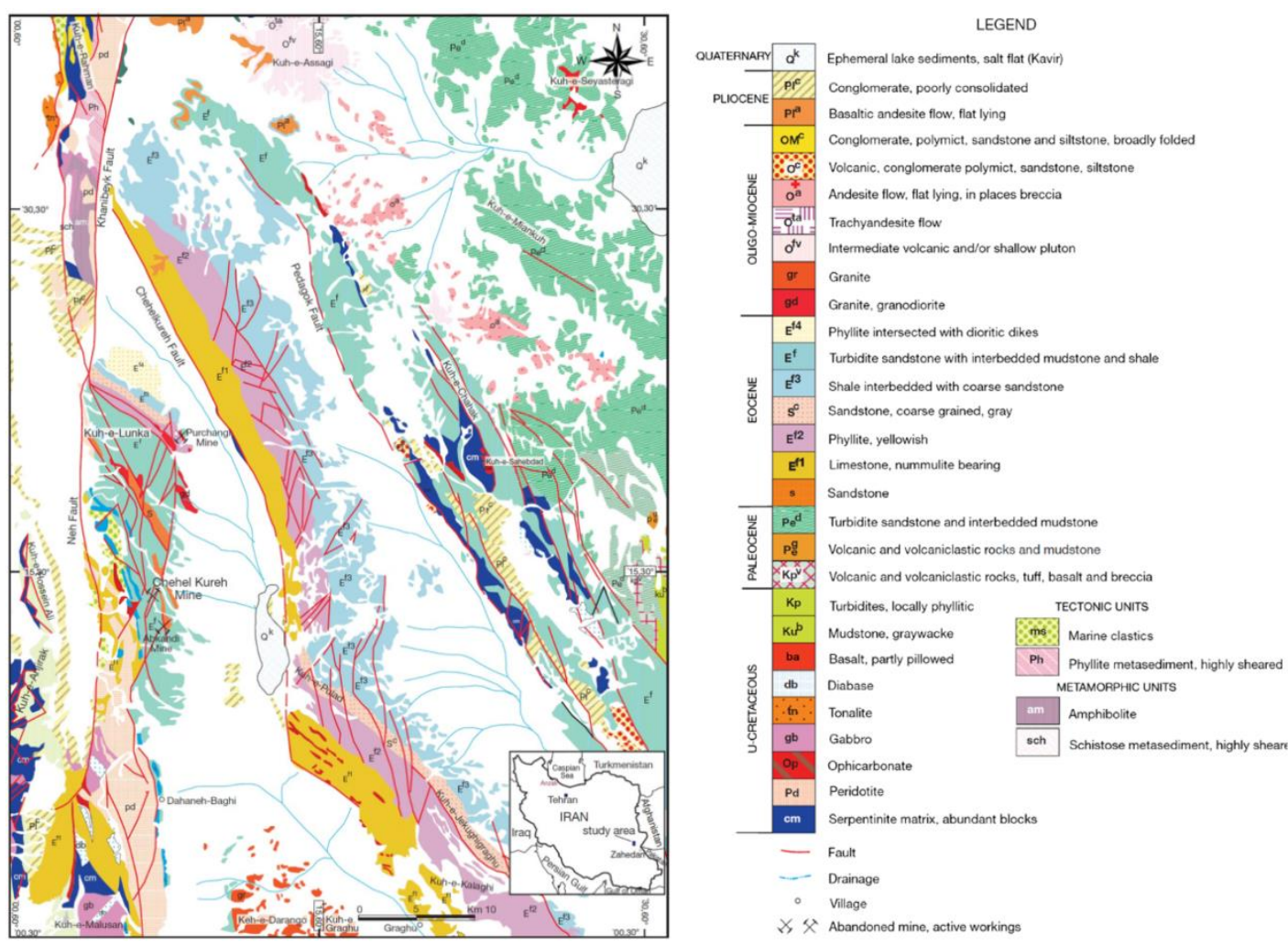

Figure 2. Regional geologic map of the Chelkureh ore deposit [8]

The Chelkureh deposit comprises numerous lenses and veins. There were two stages of mineralization, the first of which consists of metallic mineralization concentrated along the brittle, finely fractured parts of the beds of sandstone, siltstone, and shale. The second stage of mineralization formed along fractures that crosscut sandstone, siltstone, and shale, displacing them by several millimetres.

\section{Statistical analysis on data}

This deposit was explored principally by 48 boreholes (Fig. 3) totaling to $2,976 \mathrm{~m}$ of drilling. In general, the drilling grid is irregular; the distance between two boreholes varies from $50 \mathrm{~m}$ to $100 \mathrm{~m}$ (Fig. 3).

Borehole samples were analyzed by ICPMS method. They were of unequal length.
It is very important in estimation to work with equal support (volume) samples. This is why the data were composited to equal lengths [10, $11]$.

Statistical studies were performed on the raw data, the results of which are shown in Fig. 4 for $\mathrm{Cu}$ concentration values more than $0.20 \%$. The histogram of the raw data (Fig. 4) was generated by GSLIB Software [12]. This regionalized variable $(\mathrm{Cu} \%)$ can be modelled using a second- order stationary random function. There is no trend of $\mathrm{Cu}$ concentration in any directions; it means that $\mathrm{Cu}$ concentration does not depend on the coordinates of samples (Fig 5, 6, 7).

Assumptions of stationary thus appear to be tenable [13]. Since the Gaussian kriging method was not used in this study, the data were therefore not normalized and raw data can be utilized [4]. 


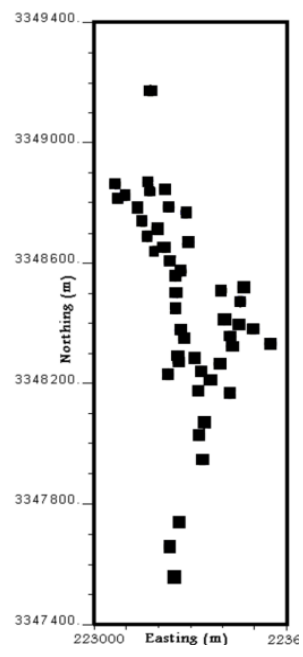

Figure 3. Borehole location map of Chelkureh deposit

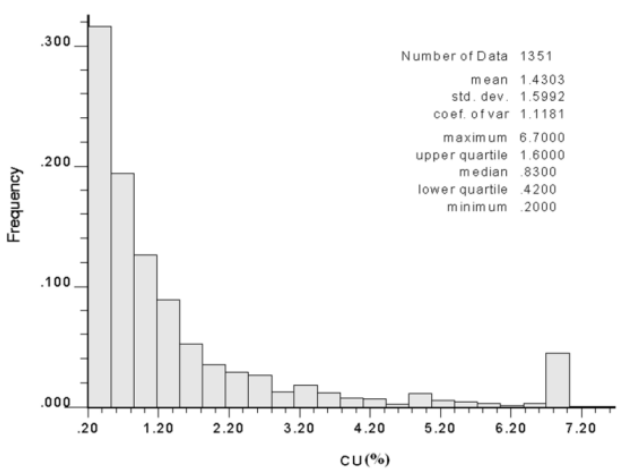

Figure 4. Histogram of the data for Chelkureh deposit

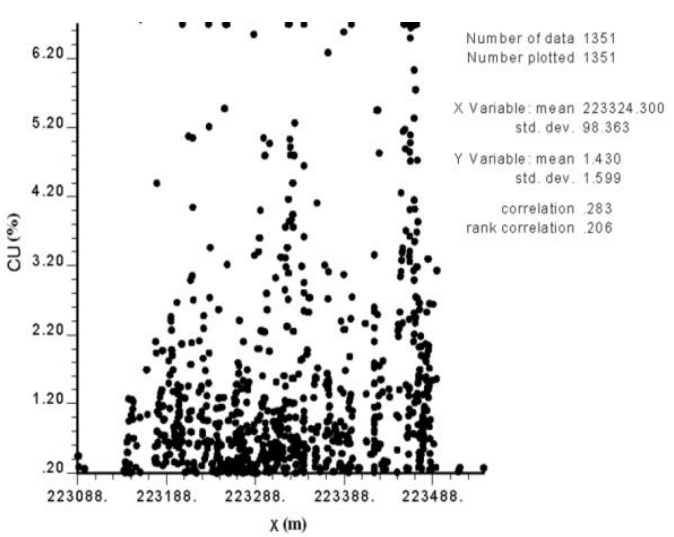

Figure 5. Variability of $\mathrm{Cu}$ concentration in east-west direction for Chelkureh deposit

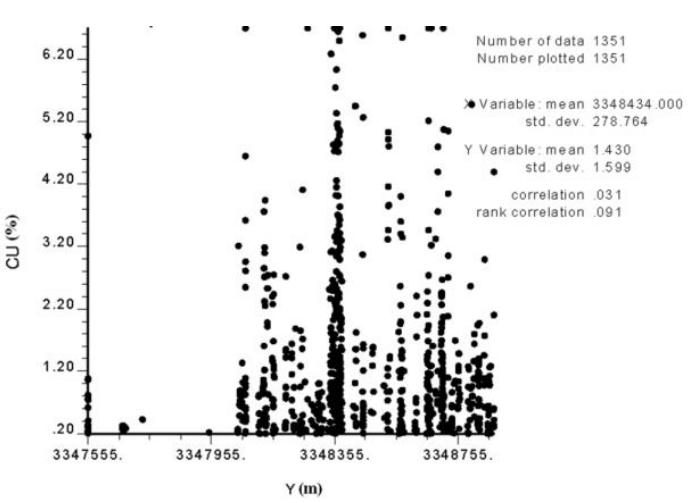

Figure 6.Variability of $\mathrm{Cu}$ concentration in north-south direction for Chelkureh deposit

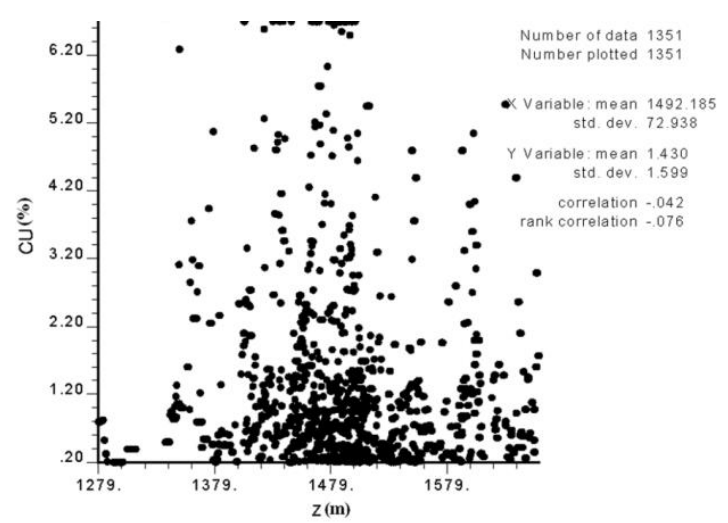

Figure 7. Variability of $\mathrm{Cu}$ concentration depth for Chelkureh deposit

\section{Discussion}

\subsection{Variography and anisotropic ellipsoid}

Variogram modelling and estimation is extremely important for structural analysis and spatial interpolation [14]. They are widely used tools for spatial interpolation, which are the fundamental parameters for geostatistical modeling $[4,15,16]$. The experimental variogram displays several important features [3].

The variogram models may consist of simple models, including: Nugget, 
Exponential, Spherical, Gaussian, Linear, and Power model or the nested sum of one or more simple models $[2,14,17]$. The most commonly used model in mining industry is spherical model. In the current study the
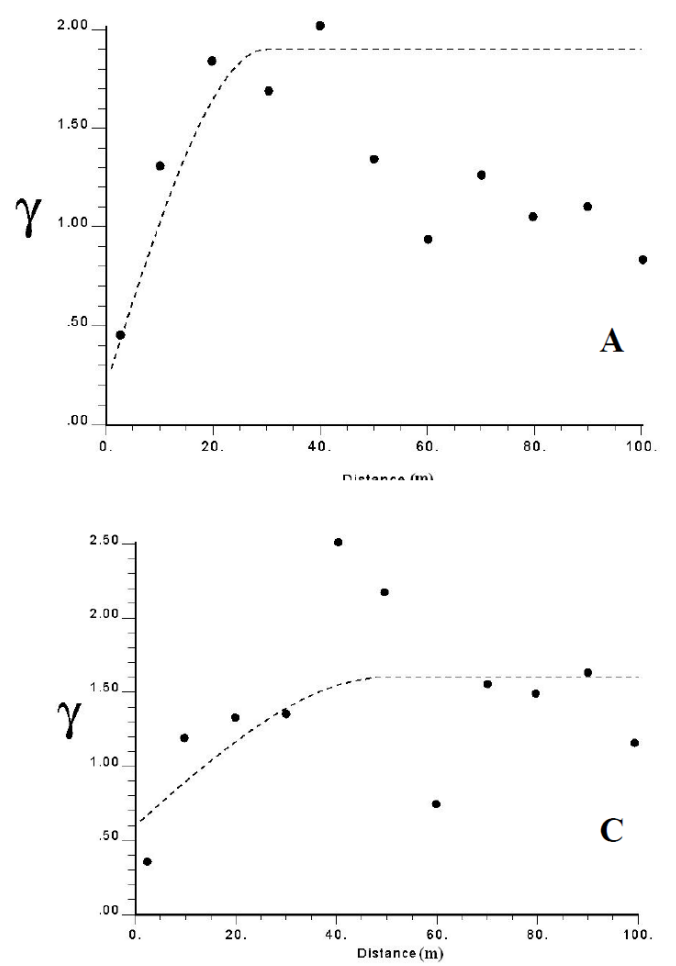

spherical model was used. In this study, the non-directional and directional variograms were generated by GSLIB Software [12] in the Chelkureh deposit, as shown in Fig. 8.
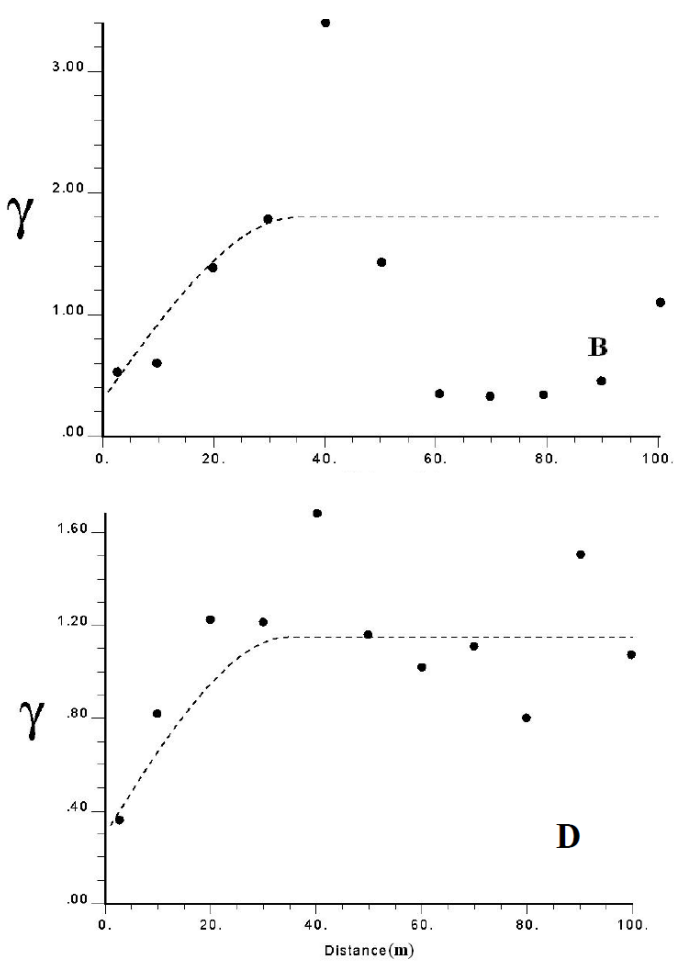

Figure 8. Non-directional and directional variograms: A non-directional, B North-South direction, C East-West direction, and D Vertical direction

After studying of variograms in different direction (Fig 8: B, C, D) it was found out that the ore deposit has no anisotropy, because in most of the variograms same ranges were obtained. The best fitted variogram model (Fig. 8 D) is considered for ordinary kriging estimation. Cross-validation was used to evaluate the accuracy of the variogram model for kriging (Fig. 9). In this procedure, every known point is estimated using the values at the neighborhoodaround it, but not itself [18].

After trial and error process of the cross validation a variogram with the best summary statistics is chosen. Model consists of a pure nugget effect with 0.30 plus a spherical scheme with sill 1.10 and range $30 \mathrm{~m}$. This model is required since ordinary kriging estimation will be based on.

\subsection{Evaluation by ordinary kriging method}

Kriging is considered as a group of geostatistical methods for the interpolation of different regional variable' values which consists of Ordinary kriging (OK), universal kriging, indicator kriging, co-kriging and others [19]. 


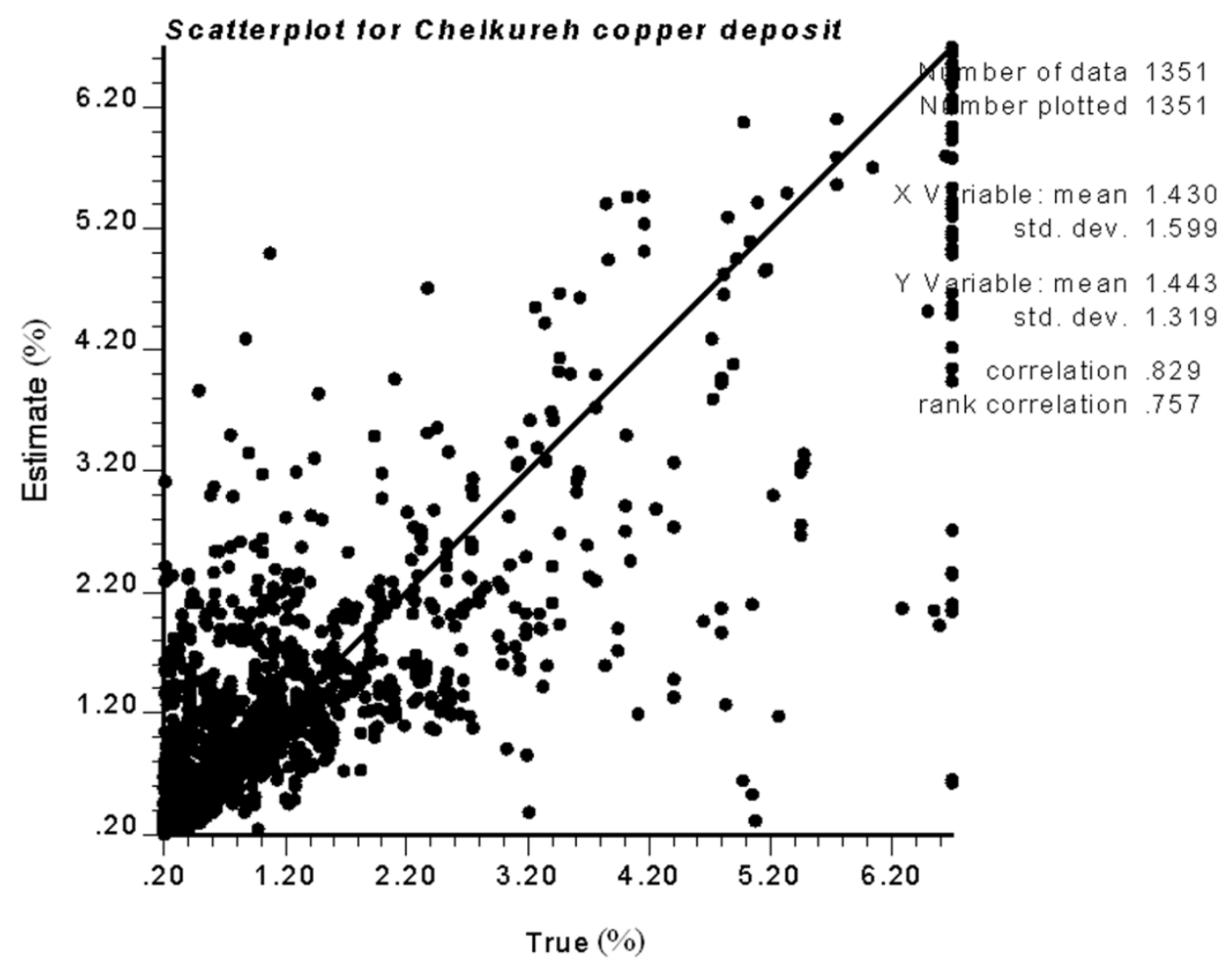

Figure 9. Cross validation diagram for real and estimated values of $\mathrm{Cu}$ inChelkureh copper ore deposit

OK estimator is a proper method in ore control and reserve/resource estimation. Kriging is commonly described as a minimum variance estimator. The choice of which kriging method to be used depends on the characteristics of the data and the type of spatial model. The theory and practice of $\mathrm{OK}$ are well known and will not be presented here. Readers can refer to Matheron (1970), Journel and Huijbregts (1978), or David (1977) for more details. The most commonly geostatistical method is OK which was selected for this study. OK was developed by Matheron in the 1960's to address the estimation of average block grades by weighting surrounding samples according to the semivariogram. OK plays a special role because it is compatible with a stationary model, only involves the variogram, and is in fact the form of kriging that is most often used $[4,20,21]$. OK estimates based on the moving average of the variable of interest satisfying various dispersion forms of data, e.g., sparse sampling points $[4,21,22]$. OK works under the assumption of a stationary condition. Moreover, it is a linear model based on local neighborhood structure $[4,23]$.

To estimate the $\mathrm{Cu} \%$, the ordinary kriging method was used to get estimates at points on a grid $20 \mathrm{~m} \times 20 \mathrm{~m} \times 10 \mathrm{~m}$. 

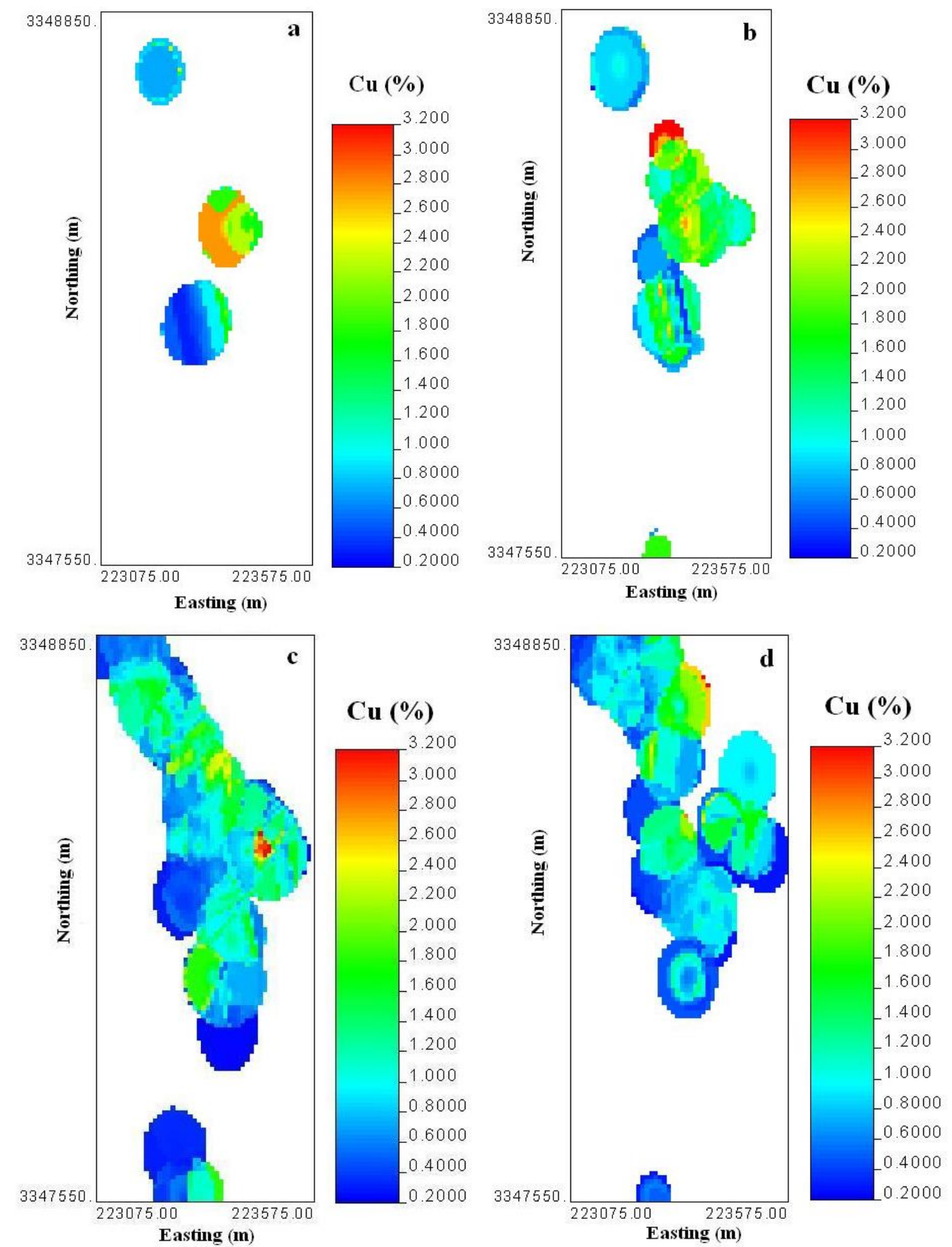

Figure 10. Estimates of $\mathrm{Cu}$ concentration by ordinary kriging in different elevations $(\mathrm{a}=1,330 \mathrm{~m}$, $\mathrm{b}=1,380 \mathrm{~m}, \mathrm{c}=1,480 \mathrm{~m}, \mathrm{~d}=1,580 \mathrm{~m}$ above the sea level) in Chelkureh deposit 

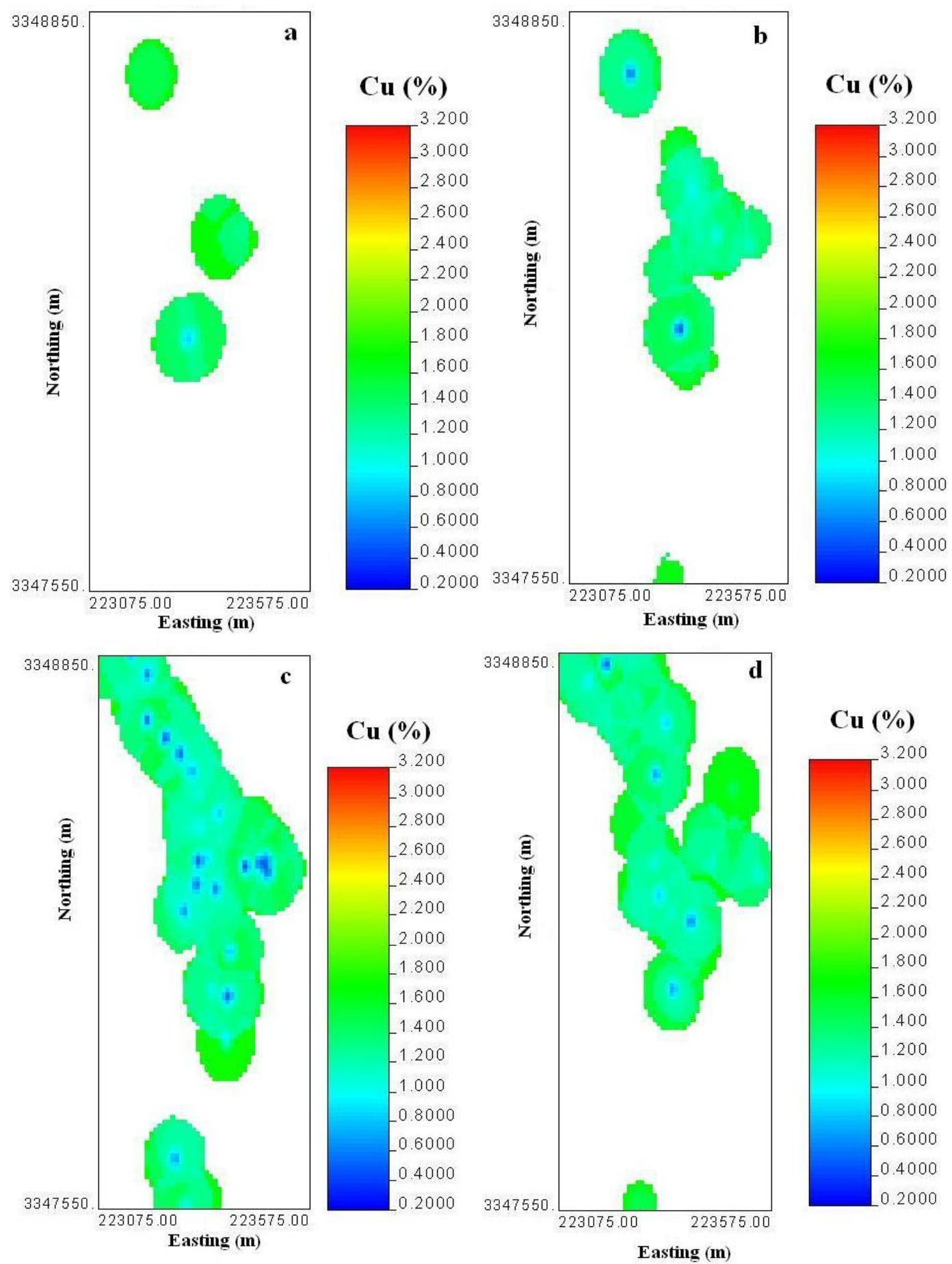

Figure 11. Ordinary kriging errors of $\mathrm{Cu}$ concentration in different elevations $(\mathrm{a}=1,330 \mathrm{~m}$, $\mathrm{b}=1,380 \mathrm{~m}, \mathrm{c}=1,480 \mathrm{~m}, \mathrm{~d}=1,580 \mathrm{~m}$ above the sea level) in Chelkureh deposit 
These points may be taken as the centerpoints of cubes of dimension $20 \mathrm{~m} \times 20 \mathrm{mx}$ $10 \mathrm{~m}$. The estimation and 3-D modelling process commenced from the elevation of $1,280 \mathrm{~m}$ above the sea level to $1,670 \mathrm{~m}$ above the sea level in the mine. It also began from $223,075 \mathrm{~m}$ to $223,575 \mathrm{~m}$ in the east direction and from $334,755 \mathrm{~m}$ to $3,348,850 \mathrm{~m}$ in the north direction (Fig. 10, 11). For the application of OK, GSLIB Software [12] has been used. Fig.10 and Fig.11, respectively, show kriging estimates and kriging errors of
$\mathrm{Cu}$ concentration in different elevations above sea level computed by OK.

Three dimensional modelling of grade in an ore deposit has a lot of advantageous. Therefore if this process is done carefully, evaluations and judgments about different parts of ore deposit would be better. Fig.12 and Fig.13, respectively, show the three dimensional model of kriging estimates and kriging errors in Chelkureh copper deposit. Miners can interpret which part is ore and which part is waste.

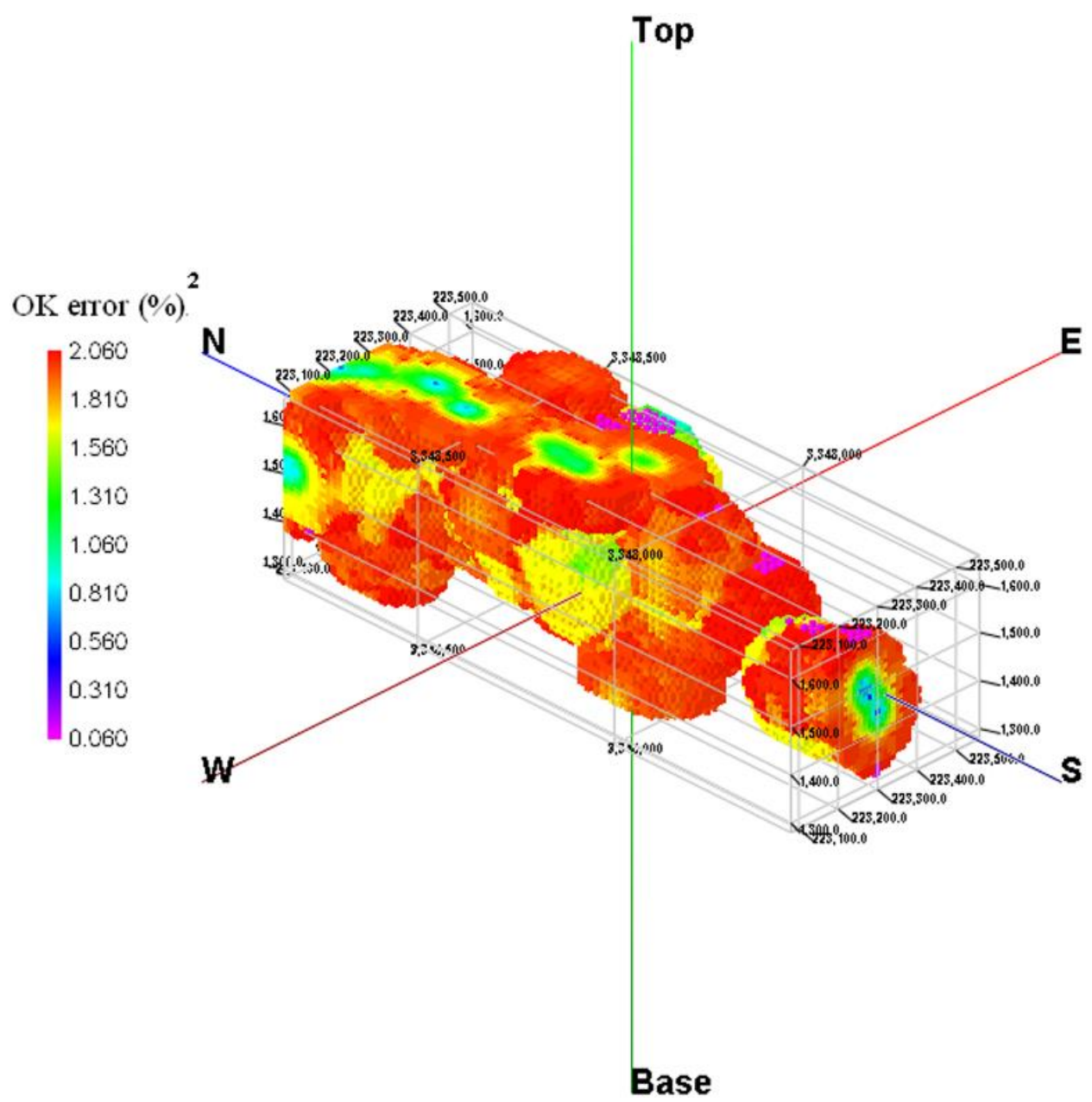

Figure 12. 3D model of estimates of $\mathrm{Cu}$ concentration by $\mathrm{OK}$ 


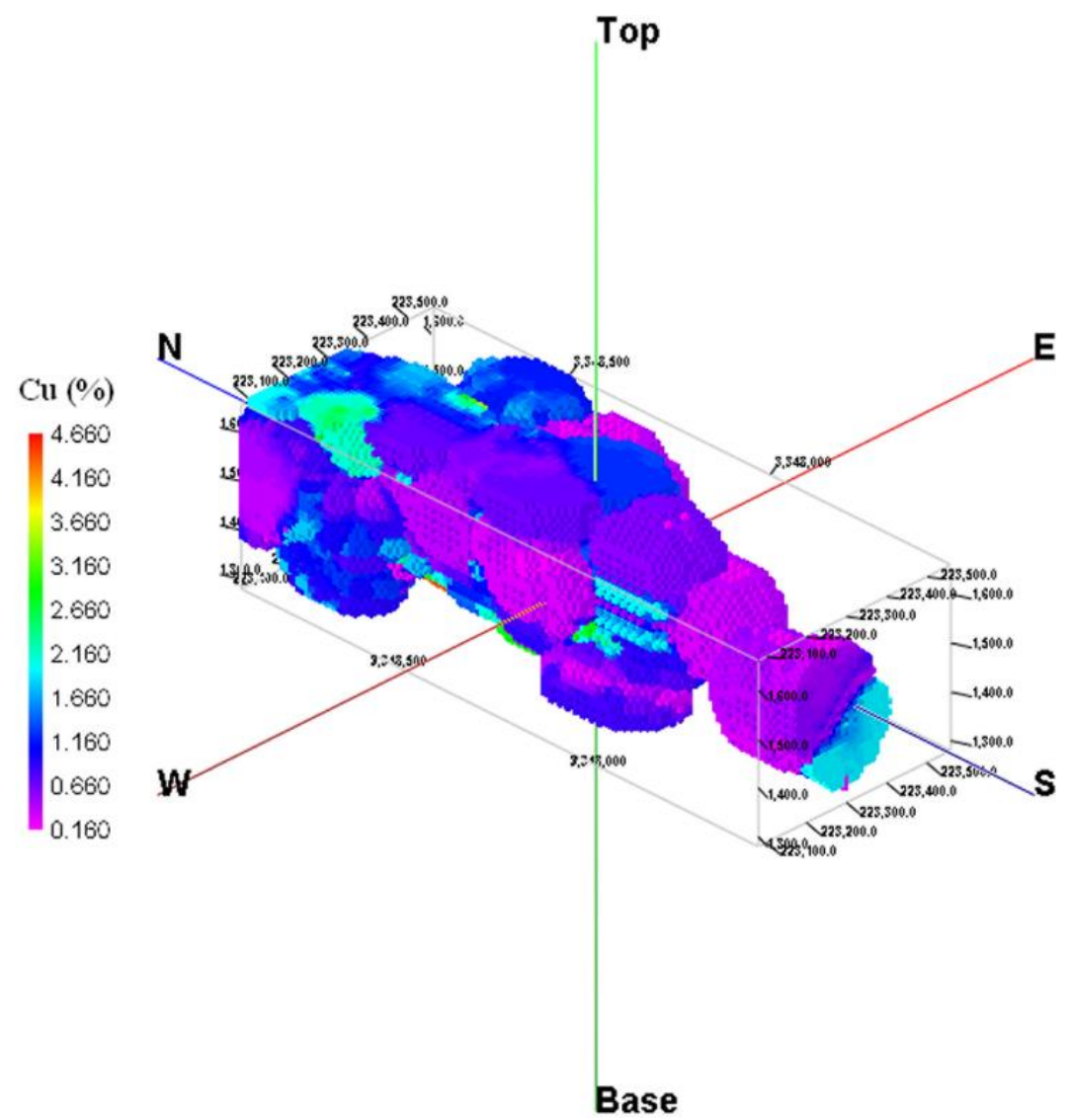

Figure 13. 3D model of kriging errors of $\mathrm{Cu}$ concentration

\subsection{Classification of the resource}

In ore estimation it is necessary to calculate the error of each voxel and the classification of resources. The following formula for calculation of the estimation error is used [20]:

$$
\% \text { Error }=\left(\frac{\text { Z.S }}{X \cdot \sqrt{\mathrm{N}}}\right) \times 100
$$

$\mathrm{S}, \mathrm{X}$ and $\mathrm{V}$ are the standard deviation of each voxel, assay of each voxel and the number of samples that are participating in the grade estimation, respectively. $\mathrm{Z}$ is the integer constant, which is 1.96 if the confidence level is $95 \%$ or 1.64 if the confidence level is $90 \%$. In this study, the confidence level assigned to $\mathrm{Z}$ was $90 \%$ hence a $\mathrm{Z}$ of 1.64 was used.
The resource estimated by OK method was classified based on error estimation. The JORC (2012) method was selected to classify the resource, as shown in Table 1.

Table 1. Resource classification based on JORC standard

\begin{tabular}{cccc}
\hline $\begin{array}{c}\text { Error } \\
(\%)\end{array}$ & $\begin{array}{c}\text { Average } \\
\text { Grade }(\%)\end{array}$ & $\begin{array}{c}\text { Tonnage } \\
(\%)\end{array}$ & Class \\
\hline $0-20$ & 1,12 & 92,66 & $\mathrm{~A}$ \\
$20-40$ & 0,41 & 7,34 & $\mathrm{~B}$ \\
$40-60$ & - & - & $\mathrm{C}$ \\
$>60$ & - & - & Possible \\
Total & 1,054 & 100 & \\
\hline
\end{tabular}


The classification framework based on the prepared code by the Joint Ore Reserves Committee of the Australasian Institute of Mining and Metallurgy, Australian Institute of Geoscientists and Minerals Council of Australia (JORC code), which is one of the international standards for mineral resource and ore reserve reporting, provides a template system that conforms to international society requirements [29].

Most parts of the estimated block model derived via the OK method (higher than $92.66 \%$ ) were classified in the A category based on JORC standard (Table 1). $7.34 \%$ of the estimated tonnages by the OK method were categorized in the B class (Table 1).

\subsection{Grade-tonnage curve}

Grade-tonnage curves are one of the tools which enable themine managers to determine the correct long-time, mean-timeand shorttime parameters for ore producing. Drawing grade-tonnagecurves needs to finding the tonnage of different grades. Tofind the tonnage of each block, the specific gravity of ore and corerecovery percent is required. So according to this data, we couldcalculate the deposit based on different cut-off grades.

Fig. 14 showsthe grade-tonnage curve of Choghart north anomaly iron ore deposit.

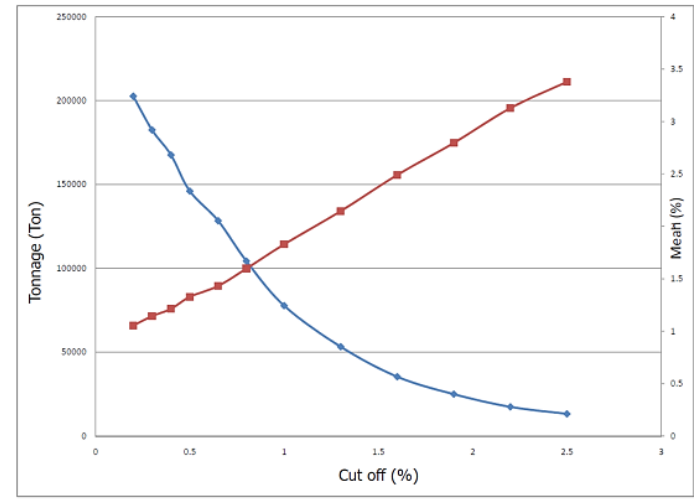

Figure 14. Tonnage grade curve of Chelkureh copper ore deposit
It could be seen that with reducing the cutoff grade of ironthe amount of deposit increases and with increasing the cut-offgrade the amount of deposit decreases.

\section{Conclusion}

Choosing the proper method for estimation of reserve with a minimum error is very important in geostatistical operations in mining engineering. The case study presented in this paper show that ordinary kriging (OK) is a useful method in the estimation of reserves or resources of vein type deposits, such as in Chelkureh copper deposit.

After trial and error a variogram with the best summary statistics was chosen. Model consists of a pure nugget effect with 0.30 plus a spherical scheme with sill 1.10 and range 30 $\mathrm{m}$. The cross validation results show that the correlation coefficient between estimated and real data is 0,829 .

The total tonnage of the ore deposit based on various cut-off grades is different and with $0,20 \%$ cut-off grade are 200000 tones, with $0,5 \%$ cut-off grade are 150000 tones and with $0,80 \%$ cut-off grade are 100000 tones.

Classification of reserve has been carried out successfully by JORC standard. Highgrade reserves including $92.66 \%$ of reserve have errors less than $20 \%$ based on estimation by $\mathrm{OK}$ technique. Based on results obtained by OK method, parts of the highgrade reserves that include $7.34 \%$ of reserve have an error between 20 to $40 \%$. It is hoped that this example taken from very different application fields will encourage practitioners in applying OK with variety of ore deposits.

\section{References}

[1] Zhang, J., Yao, Na. (2008) TheGeostatistical Framework for Spatial Prediction. Geo-spatial Information Science 11(3): 180-185. 
[2] Webster, R., Oliver, M. (2001) Geostatistics for Environmental Scientists. John Wiley \& Sons, Ltd, Chichester, 271.

[3] Wackernagel, H. (2003) Multivariate Geostatistics: An Introduction with Applications. Springer, Berlin, 387.

[4] Shahbeik, Sh., Afzal, P., Moarefvand, P., Qumarsy, M., 2014. Comparison between Ordinary Kriging (OK) and Inverse Distance Weighted (IDW) based on estimation error Case study: in Dardevey iron ore deposit, NE Iran. Arabian Journal of Geosciences, Arab J Geosci 7: 3693-3704.

[5] Stocklin, J., Eftekhar-Nezhad, J., Hushmand-Zadeh, A. (1972) Central Lut reconnaissance, east Iran. Geological Survey of Iran, Report 22, 62.

[6] Tirrul, R., Bell, I.R., Griffis, R.J., Camp, V.E. (1983) The Sistan suture zone of eastern Iran. Geological Society of America Bulletin 94, 134-150.

[7] Desmons, J., Beccaluva, L. (1983) Midoceanic ridge and island arc affinities in ophiolites from Iran: Paleogeographic implication. Chemical Geology, 39: 3963.

[8] Maanijou, M., Rasa, I., Lentz, R.D. (2012) Petrology, geochemistry, and stable isotope studies of the Chelkureh $\mathrm{Cu}-\mathrm{Zn}-\mathrm{Pb}$ deposit, Zahedan, Iran. Economic Geology 107: 683-712.

[9] Valeh, N., Saeedi, A. (1989) Geological map of Chelkureh: Geological Society of Iran, Sheet 8050, scale 1:250,000.

[10] Daya, A.A. (2013) Application of median indicator kriging in the analysis of an iron mineralization. Arabian Journal of Geosciences, in press.

[11] Daya, A.A., Bejari, H. (2014) A comparative study between simple kriging and ordinary kriging for estimating and modeling the $\mathrm{Cu}$ concentration in Chehlkureh deposit, SE
Iran. Arabian journal of Geosciences, In press.

[12] Deutsch, C.V., Journel, A.G. (1998) GSLIB: Geostatistical software library and user's guide, second ed. Oxford University Press, New York, NY, 369.

[13] Daya, A.A. (2014) Application of disjunctive kriging for estimating economic grade distribution in an iron ore deposit: a case study of the Choghart North Anomaly, Iran. J GeolSoc India 83: 567-576.

[14] Burrough, P.A., McDonnell, R.A. (1998) Principles of Geographical Information Systems. Oxford University Press, Oxford, 333.

[15] VerHoef, J.M., Cressie, N. (1993) Multivariable spatial prediction. Math Geol 252: 219-239.

[16] Calder, C.A., Cressie, N. (2009) Kriging and variogram models. Elsevier, Oxford, 49-55.

[17] Pebesma, E.J. (2004) Multivariable geostatistics in $\mathrm{S}$ : the gstat package. Computer \& Geosciences, 30: 683-691.

[18] Isaaks, E.H., Srivastava, R.M. (1989) Applied Geostatistics. Oxford University Press, New York, 561.

[19] Emery, X. (2005) Simple Kriging and Ordinary Multigaussian Kriging for Estimating recoverable Reserves. Math Geol, 37: 295-319.

[20] Chiles, J.P., Delfiner, P. (1999) Geostatistics: Modeling Spatial Uncertainty. Wiley, New York, NY, 695.

[21] Afzal, P., FadakarAlghalandis, Y., Khakzad, A., Moarefvand, P., Rashidnejad Omran, N. (2011) Delineation of mineralization zones in porphyry $\mathrm{Cu}$ deposits by fractal concentration-volume modeling. J GeochemExplor 108: 220-232.

[22] Goovaerts, P. (1977) Geostatistics for Natural Resources Evaluation, Oxford University Press. 
[23] Tahmasebi，P., Hezarkhani, A. (2010) Application of adaptive neuro-fuzzy inference system for grade estimation; case study, Sarcheshmeh porphyry copper deposit, Kerman, Iran. Australian Journal of Basic and Applied Sciences 4: 408-420.

[24] Stocklin, J.O. (1977) Structural correlation of the Alpine ranges between Iran and Central Asia. Mémoires Hors SérieSocGeol France 8: 333-353.

[25] Matheron, G. (1970) La théorie des variables régionalisées, etses applications. Les cahiers du Centre de MorphologieMathématique. Ecole des Mines de Paris. Centre de géostatistique.

[26] JORC (2012) Australasian Code for Reporting of Identified Mineral Resources and Ore Reserves (The JORC Code), The Joint Ore Reserves Committee of the Australasian Institute of Mining and Metallurgy, Australian
Institute of Geoscientists, and Minerals Council of Australia.

[27] Journel, A.G., Huijbregts, C.J. (1978) Mining Geostatistics. Academic Press, London, 600.

[28] Krige, D.G., 1951. A statistical approach to some mine valuations problems at the Witwatersrand. Journal of the Chemical, Metallurgical and Mining Society of South Africa, 52: 119-139.

[29] Asghari, O., MadaniEsfahani, N. (2013) A new approach for the geological risk evaluation of coal resources through a geostatistical simulation. Case study: Parvadeh III coal deposit. Arab J Geosci 6: 957-970.

[30] David, M. (1977) Geostatistical Ore Reserve Estimation. Elsevier, Amsterdam.

[31] Tirrul, R., Bell, I.R., Griffis, R.J., Camp, V.E. (1983) The Sistan suture zone of eastern Iran. Geological Society of America Bulletin 94: 134-150. 